\title{
Career anchors of young people: the experience of Russian studies (overview)*
}

\section{Orientación profesional entre los jóvenes de Rusia: un repaso de estudios realizados (repaso)}

\author{
Polyanskaya Ekaterina \\ Peoples' Friendship University of Russia (RUDN University), Moscow, Russian \\ Federation \\ ORCID: https://orcid.org/0000-0003-2999-1082 \\ Nikitina Vlada \\ Peoples' Friendship University of Russia (RUDN University), Moscow, Russian \\ Federation \\ ORCID: https://orcid.org/0000-0003-0780-3140 \\ Abbasova Aida \\ Peoples' Friendship University of Russia (RUDN University), Moscow, Russian \\ Federation \\ ORCID: https://orcid.org/0000-0002-8611-5073
}

Received 07-07-20 Revised 07-25-20 Accepted 09-13-20 On line 09-30-20

*Correspondence

Email: olfiss@ @list.ru
Cite as:

Polyanskaya, E. \& Abbasova A., \& Nikitina V. (2020). Career anchors of young people: the experience of Russian studies (overview). Propósitos y Representaciones, 8 (SPE3), e789. Doi: http://dx.doi.org/10.20511/pyr2020.v8nSPE3.789 


\section{Summary}

The article strives to analyze, systematize and consolidate the findings of empirical research into career orientations of Russian youth through the prism of E. Schein's anchor conception and on the basis of the various versions of his questionnaire. It was revealed that career orientations in adolescence are characterized by low differentiation, declarative nature, low awareness and contradiction. The article shows that youth career anchors are conditioned by such factors as the year of training, gender, training orientation and type of occupation. Female students are generally inclined towards stability, career-family balance and orientation to service, while male students or, in a broader scope, those with masculine-type personality put more value on management.

Keywords: career orientation, career preference, career anchor, career goal, work goal.

\section{Resumen}

El objetivo del presente artículo es analizar, sistematizar y sintetizar los estudios empíricos en relación a la orientación profesional de los jóvenes en Rusia realizados sobre la base de la teoría de anclas de E. Shein con el uso de varias versiones de su cuestionario. Se ha llegado a la conclusión de que la orientación profesional en la etapa juvenil se distingue por su carácter poco diferenciado, declarativo y por ser contradictoria y poco consciente. Las anclas de carrera entre los jóvenes están condicionadas por tales factores como etapa de los estudios, perfil de los estudios, ámbito de especialización, género y sexo. Por lo general, las chicas tienden a la estabilidad, el deseo de conciliar la carrera con la familia, están orientadas a servir, mientras que las tendencias administrativas suelen prevalecer entre chicos e individuos con personalidad masculina.

Palabras clave: orientación profesional, preferencias profesionales, anclas de carrera, objetivo profesional, objetivo laboral.

\section{Introduction}

Career is an interdisciplinary problem, a multifaceted phenomenon that might be considered through the prism of pedagogy, sociology, economic theory, management, personnel management and psychology. Fundamental psychological research in the field of career dates back to the 1960-1970 and is associated with the names of D.E. Super (1983), the author of the widely known book "The Psychology of Careers" and the theory of professional selfdetermination; D.V. Tiedeman (1963), the author of the concept of professional development; J. Holland (1985) and A. Roe (1956), who offered the typology of professional interests and classified careers from a psychological standpoint. That same period was also marked by works of E. Schein (1990), the author of one of the first textbooks in organizational psychology and the concept of Career Anchors.

For D.E. Super (1981) a successful career is conditioned by making the right career choices; he maintains that job satisfaction (and in a broader scope, life satisfaction) depends on how well can an individual find ways to realize his or her potential, interests and personal traits in a work situation. He also asserts that career prospects of an individual are determined by his or her idea of one's own personality, the so-called "professional self-concept", which an employee embodies in a series of career decisions. Thus, professional preferences and the type of career is an attempt to answer the question "Who am I?". It should be noted though that very often an individual is unaware of it and implements his/her career orientations unconsciously.

\section{The extent of prior research}

Young people are looking at formidable tasks to find their calling and place in life and pursue professional socialization and self-realization in the modern rapidly changing world where 
many countries are facing serious political, economic and social challenges. With market economy undergoing globalization processes, academic mobility on the rise and values changing, special relevance is gained by studies into youth preferences regarding their career choices. This paper strives to analyze and consolidate the data of empirical studies into youth career anchors in Russia today.

It was not until 1980-1990 that the term "career" was much used in Soviet scientific literature; in the public eye the word itself was regarded as having negative connotations. This perspective was mainly adopted due to the dominance of the ideas of social equality in the official propaganda. "To make a career" meant a conscious strive to elevate above others with the only purpose to obtain personal advantage in the process of public wealth distribution. Career-seekers were unambiguously disapproved of morally. Russian science widely used such concepts as "professional prospects", "professional growth", "promotion", which all in all virtually substituted the rejected concept of "career" and were eventually laid at the basis of Russian conceptions of professional development (such as the akmeological conception of professional development by A.A. Derkach and V.V. Zazykin (2003), professional development conception by L.M. Mitina (1998), conceptions by Y.P. Povarenkov (2002), E.F. Zeer (2012).

A.A. Derkach was one of the founders of akmeology - the science, studying mechanisms of reaching top stages in individual development. He looks at professionalism as a system embracining two interconnected subsystems - occupational professionalism and personal professionalism. The former entails high qualification, a variety of effective skills, etc, while the latter includes personality traits important for the profession, motivational sphere, values, etc. (Derkach \& Zazykin 2003).

Another Russian psychologist, L.M. Mitina (1998) identified and described basic psychological factors, conditions, mechanisms and driving forces behind creative self-realization within the occupation (teaching). Her concept is based on the principles of mental development, formulated in the cultural-historical psychology and the theory of consciousness by L.S. Vygotsky as well as on the activity theory by A.N. Leontief and S.L. Rubinstein and the theory of child personality development by L.I. Bozhovich, V.V. Davydov, D.B. Elkonin and others (Mitina 1998).

S.D. Churkin, T.D. Dubovitskaya, E.B. Maslov (2012) outlined basic stages of professional development - the initial stage when professional intentions first emerge (choice of a career); direct vocational training; getting started in the workplace, full individual selfrealization in the occupation. Y.P. Povarenkov (2002), E.F. Zeer (2003), also came up with their own perspective on stages and periods within professional development of an individual. However, in a modern post-industrial society, qualifications obtained in an educational institution often turn out to be unclaimed with many graduates unable to find a job in the sphere they are trained for. Getting extra qualifications is becoming increasingly common, with the system of ongoing education gaining further recognition (advanced training, professional re-training, vocational training courses) (Zeer 2012). Professional pursuit and, accordingly, the emphasis on self-realization in the chosen area lose its relevance. Social and economic reforms implemented in Russia, made the scholars turn to Western experience in education and management and provoked a deep interest in foreign conceptions of career choices.

\section{Discussion.}

\section{Career anchors}

A very important component of self-concept is the so-called career orientations, defined as one's visions of own abilities, values, motives, meanings and needs related to professional promotion (Zhdanovich 2008; Pochebut \& Chiker 2000). One of the widely recognized conceptions in the study of career orientations was the theory of career anchors by E. Schein. According to this scholar, "career anchors" is one element in a person's self-concept (self-image), his or her vision of oneself, his/her talents and abilities, basic values, needs, motives that determine career choices. E. Schein identifies eight of such "career anchors": 
1) Technical/Functional competence - the desire to be an expert in a certain field, develop one's talent and skills in those areas; 2) Autonomy/Independence - reluctance to be bound by any norms and rules of an organization (working hours, dress code, etc.), this type of professionals need to do things in their own way which make them pursue an independent career; 3) Security/Stability - craving for security and stability in the workplace, predictability of the future, with two types of stability involved- domicile stability and job stability; 4) Entrepreneurial Creativity - the desire to create one's own business to develop a new service or product; 5) Pure Challenge - the desire to conquer anything or anybody, focus on competition, victory over others, overcoming obstacles, solving difficult problems; 6) General Management Competence - the desire to lead others and focus on managerial activities; 7) Service/Dedication to a Cause - the desire to help people and make the world a better place; 8) Lifestyle - the desire to integrate the needs of the individual, the family, the career (Schein 1990).

In Russia, Schein's questionnaire commonly known as Career Orientation Inventory (COI) was adapted by L.G. Pochebut and V.A. Chiker (2000), who in their work Organizational Psychology for the first time presented the results of the study into career orientations conducted on the basis of this technique in various sample groups of Russian youth (400 people in total). Since the 2000s Russian scholars have applied E.Schein's perspective in a number of research into career anchors of various population categories. This article presents an overview of studies into career preferences of young people, performed by different researchers on different sample groups of youth.

The work by L.G. Pochebut and V.A. Chicker presents the results of a study into career anchors in schoolchildren, college students and university undergraduates. For schoolchildren the dominating career anchors are Lifestyle, Autonomy and Service; college students prefer Lifestyle, Autonomy, Security/Stability; while most university undergraduates stick to Service, Lifestyle, and Autonomy (Pochebut \& Chiker 2000). Thus, for the young people on the whole, preferable career anchors are Lifestyle and Autonomy. Their career preferences are of social nature, they are generally unrelated to the professional orientation towards a specific occupation, perhaps, to a certain extent they reflect age-related features such as craving for independence, idealism, strive to make the world a better place, etc.

\section{Influence of future profession on career preferences of youth}

At the same time, it is obvious that young people do not constitute a homogeneous social stratum. Further research shows that career anchors of university undergraduates specifically depend on their specialty of training, occupation and gender. Girls are more likely to choose such career anchors as Security, Service and Lifestyle; they are much less likely to choose Entrepreneurial Creativity and General Management Competence, the least value was put on such anchors as Autonomy and Pure Challenge (Pominova 2001; Yurtaeva 2012). The authors agree that these are typical choices within female gender roles and are related to the need for security, predictability of the future, thoughtfulness to others, and desire to balance work and other aspects of life.

However, the most important factor behind career preferences lies in the nature of the specialty of training.

Among those studying management typical career anchors are consistent with the requirements of their future profession with high scores on General Management Competence, Entrepreneurial Creativity, Lifestyle and Autonomy (Mogilevkin \& Novgorodova 2011; Churkin \& Dubovitskaya \& Maslova, 2012; Tsaritsentseva, 2009). This indicates that future career is visualized as having to do with management and entrepreneurship, as well as with the balance of various aspects of life, freedom from organizational rules, regulations and restrictions. At the same time, such a perception of future career turns out to be too optimistic; the students do not seem to realize that their future business success will be largely dependent on their personal professional achievements (as reflected in by far the lowest score on Technical/Functional competence). E.A. Mogilevkin and A.S. Novgorodov further modify E. Schein's technique and show that prospective career preferences do not necessarily coincide with actual career anchors. For example, most students prefer a vertical managerial career in the future, but at the present moment the score on General Management Competence is comparatively lower. Contradictions 
are also noted for the anchors of Lifestyle, Service, Technical/Functional competence, Pure Challenge. It turns out that during the training Management undergraduates do not see much need to develop relevant competencies, their ideas of the future career are vague, poorly outlined and contradictory (Mogilevkin \& Novgorodova 2011).

In her work looking at career orientations of university graduates applying for jobs in railway enterprises, A.S. Mironova-Tikhomirova (2006) also noted discrepancies between declared and real career preferences. The author's modification of E. Schein's technique showed that in reality Service was slightly less important than it was declared. The rankings of the real career orientations were as follows: 1) Stability 2) General Management Competence, 3) Lifestyle, 4) Service (with the declared 3rd), 5) Autonomy, 6) Pure Challenge, 7) Technical/Functional competence, 8) Entrepreneurial Creativity, 9) Place of living stability. The study found that students do not see much relation between business success and professional competencies.

Career orientations of first-year and fifth-year teacher-training college students were described in the works by T.A Terekhova (2011), O.P. Tsaritsentseva (2009). A typical career anchor for most teacher-training college graduates was Stability; with the least common being Pure Challenge and Autonomy, that is, those involving competition and freedom from restrictions and regulations. The findings are quite consistent with expectations of a career in teaching, which involves lots of cooperation and work for a stable organization. At the same time, such career anchor as Service proved most significant for those specializing in humanitarian field, while natural specialties students scored highest on Stability, and future Math and Science teachers - on Entrepreneurial Creativity. Principal career orientations of first-year students are also somewhat different from those of the graduates. The choice of Technical/Functional competence by first-year students was more pronounced, while the graduates were more inclined towards Entrepreneurial Creativity (Tsaritsentseva 2009). Such a result may be explained in the light of numerous studies into the evolution of vocation perception, which suggest that maximum vocation-related expectations are observed in first-year students, that is why most common are orientations towards "learning the ropes", while throughout the entire period of training expectations are starting to lower due to objective (unsatisfying level of teaching) and subjective (revealing the darker sides of the future profession) reasons. By the time the training is complete, the students demonstrate low awareness of career orientations as well as the presence of internal career-related conflicts. The lowest awareness indicators related to career preferences were observed in students of psychological and economic specialties, as evidenced by their inclination towards setting ambiguous goals ("someday", "somehow") and desire to simultaneously achieve success in many areas, which reflects a situation of uncertainty in professional choice.

Career anchors of Psychology students have been studied by T.A. Terekhova (2011), S.D. Churkin, T.D. Dubovitskaya, E.B. Maslova (2012), D.V. Zhuina (2013), D.G. Boguslavskaya (2014). In general, Psychology students put most value on such career anchors as Lifestyle, Service, and Autonomy. In other words, the students rate highly work-life balance, value of service and freedom from organizational restrictions. In the study by TA. Terekhova Psychology students put the career anchor of Technical/Functional competence among their preferences (it was slightly less popular with the graduates, though). In other sample groups of Psychology students Technical/Functional competence scored average in importance or even was the least significant, reflecting weak professional orientation (Terekhova 2011). Training in Psychology implies a horizontal career, at the same time many of the Psychology students chose General Management Competence among their most-valued career anchors, while correlation analysis revealed negative correlation between this type of career anchor and professional orientation (Terekhova 2011; Churkin \& Dubovitskaya \& Maslov 2012). D.V. Zhuina (2013) looked at the evolution of basic career orientations throughout different stages of training: most 
first- and second-year psychology students favored the career anchor of Autonomy, which indicates their desire to escape organizational rules, regulations and restrictions; third-year students give preference to such career anchors as Stability and General Management Competence; those in the 4th year preferred Technical/Functional competence, reflecting their consolidated desire to become highly skilled specialists in the field; while graduates scored highest on Entrepreneurial Creativity. In general, psychology students demonstrated lack of mature career orientations throughout the whole course of training. Apparently, this may be accounted for by a complex of objective and subjective factors. One of the objective factors lies in the fact that common in the West practice of turning to professional psychological expertise is rare in Russia with its general public unawareness of psychological services and prejudices against psychotherapy as something only necessary for "weak", "rich" or "insane" people (Yurevich 2008). Career prospects for psychology graduates are consequently not very clear, giving rise to a certain tendency among the graduates to try to set up a project or business of their own.

The study by S.D. Churkin, T.D. Dubovitskaya and E.B. Maslova (2012) collected data on career orientations of Law students and students of the Faculty of Physics and Mathematics. Law students scored highest on the career anchor of Technical/Functional competence with second highest rates on Service. They obviously put much value on high professionalism, are ready to constantly excel in their professional field, and crave for "making the world better", etc. Law graduates believe that success is determined by deep knowledge, high professionalism and the ability to work with people. The students of the Faculty of Physics and Mathematics also showed a correlation between their professional orientation and the career anchor of Technical/Functional competence, with very high scores on Service, which indicates a significant value of serving for the public good.

The article by E.N. Lomakina (2011) presents the results of a study into career anchors and professional orientations of engineering specialties graduates. This group's dominant career anchor was Stability with high scores on Technical/Functional competence, Lifestyle and Autonomy. Furthermore, those choosing design-and-engineering type of professional activities often give preference to the career anchor of Service; while those getting trained in production and management type of work prefer General Management Competence. Thus, the study revealed that the tasks and goals of professional activity affect the hierarchy of career anchors.

Those getting the training in Advertising demonstrate a range of values, motives and career orientations dependent on the specialty (Burmakova, 2007). Future managers and marketers are dominated by the career anchor of General Management Competence - that is the desire to coordinate other people's efforts and organize their activities - while designers and copywriters appreciate Autonomy/Independence. These differences reflect specificity in the work of marketing specialists and managers in advertising, both being the representatives of socionic professions, in comparison with that of designers and copywriters, focused on creative selfexpression. The results obtained showed that the choice of career in adolescence is largely determined by individual interests, inclinations, abilities, characteristics and values, which finds its manifestation in career orientations of first-year students.

N.I. Yurtaeva (2012), obtained data on leading career orientations of Pediatrics interns and found them to be Service, Stability, Technical/Functional competence.

Of particular interest is a pilot cross-cultural study by E.G. Shchelokova into career orientations of university students in Russia and Britain. The study reveals cross-cultural differences in both career preferences and axiological aspects of career orientations. Russian students associate career success primarily with a high leadership position, while British students are more focused on professional development, which they relate to such values as "financial standing", "personal sustainability", with the career vector "up" related to such values as "relationship", "self-development", "spiritual satisfaction" and "prestige" (Shchelokova, 2014). Initial hypothesis was quite the opposite: she associated "vertical career" with socio-pragmatic values, while "horizontal career" was associated with spiritual and moral values. Obviously values are viewed differently across different cultures with their specific meaning being directly open only to the members of this culture. Differences in career preferences can be accounted for 
by the influence of economic and socio-cultural factors, while a career itself is seen as a complex socio-psychological phenomenon.

\section{Conclusiones}

Analysis and generalization of the findings of empirical studies into career orientations of modern Russian youth enable to draw a number of conclusions.

1. Young people largely demonstrate a low level of career awareness, lack of a clear hierarchy, declarative and divergent nature of career aspirations; their current preferences are inconsistent with idealized perceptions of their future career.

2. Career preferences of the youth are affected by such factors as gender, field of training or the type of professional occupation, the year of training (the hierarchy of career anchors varies and has its own specificity in each year of training).

3. Female students in general give preference to stability, security, life-career balance and family; they are more focused on service, indifferent to independence, struggle and victory over others (high scores on such career anchors as Stability, Lifestyle, Service, with low scores on Pure Challenge or Autonomy). The orientation towards General Management Competence most often dominates in young men or masculine-type personalities; it is also common among girls who have chosen such professional fields as "management", "political science" or engineering specialties (the choice which probably reflects their masculine-type personality).

4. The hierarchy of career orientations among the students of different specialties is specialty-specific and in general corresponds to the nature of the specialty or the type of professional occupation. The findings of different studies largely coincide: managerial students score high on such career anchors as General Management Competence, Entrepreneurial Creativity, Lifestyle, Autonomy; future teachers prefer Stability, avoiding Pure Challenge and Autonomy, psychology students put much value on Lifestyle, Service and Autonomy; Law students give preference to Technical/Functional competence and Service; future designers and copywriters attach most importance to Autonomy; Pediatrics interns prefer Service, Stability, Technical/Functional competence. The data obtained in such sample groups as "students in general" or "students of engineering, physics and mathematics, etc. faculties" are too indeterminate, since the hierarchy of career anchors relies heavily on the specialization within a specific field of training.

5. The career anchor of Service is popular with the students of humanitarian and technical specialties, but it is basically of little importance for those getting trained in Advertising, Economics or Management.

6. The career anchor of General Management Competence is largely popular with the students irrespective of their focus on a certain type of occupation.

7. Specific character of career orientations of modern Russian youth is, in our opinion, largely related to objective economic and socio-cultural factors, including the situation in the labor market. According to E.F Zeer (2012), certain professional groups are vulnerable to professional deprivation, which in some cases may reach $80 \%$. All these affect career orientations of Russian youth.

8. In general, across sample groups of students in Russia, the career anchor of Technical/Functional competence is of the lowest importance, although it is supposed to be an indicator of one's professional orientation. This anchor often undergoes a significant change throughout the course of training: in early years the desire to perfectly master the chosen occupation is basically more pronounced, with subsequent decrease toward the graduation. However, this career anchor is still among most valued in certain groups of future specialists including pediatricians, lawyers, engineers and copywriters. 


\section{References}

Burmakova, Y.A. (2007) Individual Personality Factors of Professional Development of Specialists in Advertising. Abstract of dissertation, candidate of psychological Sciences. Moscow, Russia, 21

Churkin, S.D. \& Dubovitskaya, T.D. \& Maslov, E.B. (2012) Professional Orientation and Career Orientation of Students. Modern Problems of Science and Education. No. 2, 1-8

Derkach, A. \& Zazykin, V. (2003) Akmeology: textbook. St. Petersburg, Russia, 256

Holland J.L. (1985) The Self-Directed Search Professional Manual. Odessa, Ukraine, 125

Lomakina E.N. (2011) Career Orientation as Axiological Component of Professional Orientation of the Future Engineer. Scientific-theoretical journal "scientific notes of University named after P. F. Lesgaft”. No. (77), 104-110

Mitina L.M. (1998) Psychology of Professional Development of Teachers. Moscow, Russia, 200

Mogilevkin, E.A. \& Novgorodov, A.S. (2011) Research into Leading Motives of Career SelfDetermination of University Students. New Opportunities Territory. Bulletin of the Vladivostok State University of Economics and Service. The scientific journal. No. 1 (10), 59-78

Pochebut, L.G. \& Chiker V.A. (1956) Organizational Social Psychology. St. Petersburg, Russia, 298

Polyanskaya E., Fisenko O., Kulakova V. (2018) Strong-Willed Character Traits in Students' Career Orientation in the Labor Market and Self-Realization. European Research Studies Journal. Vol. XXI, Special Issue 2, 606-613 https: DOI: 10.35808/ersj/1287

Povarenkov, Y.P. (2002) Psychological Content of Professional Formation of An Individual. Moscow, Russia, 159

Shchelokova, E.G. (2014) Values and Career Orientations of University Students: A CrossCultural Aspect. SUSU Science: Proceedings of 66th Scientific Conference 15-17 April. Section of Social-Humanitarian Sciences. Semantic Content of a Career Orientation. Chelyabinsk, Russia, 1572-1580

Super, D.E. (1981) A Life Span, Life Space Approach to Career Development. Journal of Vocational Behavior. No.16, 282-298

Terekhova, T.A. (2011) Manifestations of Career Orientations of Psychology Students. Humanitarian vector. No.1 (25), 120-126

Tiedeman, D.V. \& O`Hara R.P. (1963) Career Development Choice and Adjustment. New York, USA, 136

Tsaritsentseva, O.P. (2009) Career Orientations of Modern Youth: Theory, Experiment, Training. Orenburg, Russia, 186

Yurevich, A.V. (2008) Psychology in Modern Society. Psychological Journal. Vol. 29, No. 6, 514

Yurtaeva, N.I. (2012) Management of Career Orientations in Professional Development of Students of a Technical University. Vestnik Kazanskogo tekhnologicheskogo universiteta. (Bulletin of Kazan National Research Technological University). No. 1, 300 - 306

Zeer E.F. (2012) The Concept of Professional Development of an Individual in the System of Continuous Education. Pedagogical education in Russia. Vol. No. 5, 122-127

*The publication has been with the support of the "RUDN University Program 5-100". 